\title{
Confucian and Daoist, Stoic and Epicurean. Some Parallels in Ways of Living*
}

The context for this essay is global warming, and the increasing harms humanity will suffer as a result of persisting with business as usual instead of dealing with the problem. Blocking progress are three obstructions: the financial clout of the fossil fuel industries in current politics, the political power of the religious right in the US Congress, and the attention-diverting abilities of the Internet Titans with their Information and Communication Technologies (ICT). Most of this is well-funded by a small group of libertarian billionaires.

Even if we can remove these obstructions, we still have to cooperate effectively with China (and then India, Brazil, etc) if we're to mitigate the damage from climate change. And the best way to achieve that is to acknowledge that the ancient Chinese ideas now advocated by the current Chinese government are helpfully applicable to our current predicament.

What's interesting here is that there are comparable ideas in the Western tradition, but they have traditionally been overlooked or marginalised. For example, there are significant parallels between ideas in Confucian and Daoist philosophies on the one hand, and Stoic and Epicurean thought on the other. An appreciation of these would provide common ground for more productive dialogue with the Chinese and collaboration on slowing global warming.

But even with full cooperation from China and other nations, we in the developed countries will have to reduce our consumption of energy and goods. The planet's resources are finite, and already overexploited, and we in the developed world have consumed far more than our fair share. The global injustice is glaring, insofar as the countries hardest hit by the effects of global warming are those who have contributed to it least. It shouldn't surprise us, as the hits gets harder, to find millions of climate refugees at our borders, and more than a few foreign eco-terrorists among them. Not that the developed world is immune to the dire effects of climate change, as various extreme weather events have shown.

When people hear talk of lower levels of consumption they tend to be dismayed - students especially, who haven't yet enjoyed the fullness of consumer bliss. But the ancient wisdom of both the Western and Chinese traditions sug-

\footnotetext{
* I have sometimes modified the translations slightly on the basis of the original texts and other translations.
}

Ә OpenAccess. () 2019 Graham Parkes, published by De Gruyter. (cc) BY-NC-ND This work is licensed under the Creative Commons Attribution-NonCommercial-NoDerivatives 4.0 License. https://doi.org/10.1515/9783110616804-004 
gests such dismay is misguided, insofar as these thinkers argue that high levels of consumption actually get in the way of a fulfilled human life. At more modest levels we can take more joy in things without feeling in any way deprived. It's a matter of finding out how much is enough.

By an interesting coincidence, the Stoic and Epicurean schools of philosophy were founded around the time when the two great Daoist classics, the Laozi and Zhuangzi, were taking final shape in response to the prevalence of the Confucian classics over the preceding century or two. In ancient Athens two remarkable thinkers initiated the Western conversation about "living in accord with nature": Epicurus (341-269 BCE), whose teachings became the basis for the Epicurean tradition, and Zeno of Citium (334-263 BCE, not to be confused with the earlier Zeno of Elea and his paradoxes), who was the founder of the Stoic school of philosophy.

\section{A Physics Requirement}

For all these thinkers - Confucian and Daoist, Stoic and Epicurean - the human being is best understood in context, insofar as human flourishing depends on both society and the natural environment. (The emphasis in what follows will be on the latter, in view of our current environmental predicament.) If you're going to adjust your life to the prevailing circumstances, you'd better have an understanding of what they are. The ancient Greek thinkers called the world in this sense physis, which originally had connotations of being born and growing, of unfolding and developing. At first applied to particular things, and so meaning the 'nature' of each and the ways in which it naturally grows and unfolds, physis came to mean also the whole process whereby these particular natures develop together in dynamic equilibrium. ${ }^{1}$

Epicurus taught that we attain a serene and fulfilled life first by investigating and understanding the natural world, and then by "living in conformity with nature”. Natural science (physiologia) serves to dispel primitive dread of phenomena in the heavens above us and torment from gruesome events recounted in ancient myths. It's a matter, Epicurus says, of "determining the end ordained by nature", which means understanding how the world works in the broadest

1 Hadot (2006) 17. 
sense and how we best fit in, in the sense of optimising our fulfillment and contribution to the whole. ${ }^{2}$

Epicurus is concerned that we not violate nature but rather 'obey', and that we 'follow nature' rather than 'vain opinions'. If we assess our actions only on the basis of what's closest to us, we lack perspective and a sense of the scale and space that we get from keeping in touch with nature as we act. ${ }^{3}$ The Chinese thinkers would find this attitude congenial-except for the talk of the 'end' or 'purpose' (telos) of nature, because they see the whole thing unfolding as play, which has no purpose outside itself.

Zeno was apparently the author of a book with the title Of Life in Accord with Nature (like all his other works, lost). He is said to have said that happiness consists in 'a good flow of life' - just what the Daoists and traditional Chinese medical practitioners say about well-being and qi energies. (For the Daoists the whole world is a field of qi energies of varying density and speed: rarefied and fast, as with breath; condensed and slow as with granite). Zeno's successors in the Stoic school understood living in accord with nature as two-fold: 'according to our human nature as well as the nature of the universe'. The idea is that "our own natures are parts of the nature of the whole", (M. Aur. Med.12.26), and so the task - as with their Chinese counterparts - is to harmonise microcosm with macrocosm. ${ }^{4}$

This is why the Stoics and Epicureans make physics, understood as the 'study of nature', central to their philosophies - not as a purely theoretical exercise but rather as a practice of thinking and imagining in a deeply existential mode. Here is Lucretius, expressing gratitude to Epicurus for having taught him how to pursue an experiential science of nature:

The walls of the world open out, I see action going on throughout the whole void ... Thereupon from all these things a sort of divine delight gets hold of me and a shuddering, because nature thus by your power has been so manifestly laid open and unveiled in every part. $^{5}$

When the doors of perception are cleansed by the discipline of Epicurean physics, there's a divine pleasure - divina voluptas! - and 'shuddering' (the Latin is

2 Epicurus (1926) 135, 97, 91 ('Fragments’ B, 57; 'Principal Doctrines’ XI, XII; 'Letter to Menoeceus' 133).

3 Epicurus (1926) 101, 109, 133 ('Principal Doctrines', XXV; 'Fragments' A (Vatican) XXI, 'Fragments' B, 45).

4 Diogenes (1959) 2:113; Long/Sedley (1987) 1.394-95.

5 Lucretius, On the Nature of Things, 3.17-30, translation in Hadot (1995) 88. 
horror), a shaking in the face of such an awe-inspiring vision of the cosmos and one's tiny part in it.

Marcus Aurelius, the last great Stoic thinker, had the same idea: right at the beginning of his Meditations he expresses gratitude to his teacher for advocating "life in accord with nature", and encourages himself to practise such a way of living. When he writes that "all things come to pass in accord with the Nature of the Whole", he means that since we humans exist among all things, we do well to try to get a sense of the totality and where it's tending. We can accord with nature because our own nature is subject to the 'ruling' or 'guiding principle' within us, which is one with the rational, divine power that governs the cosmos. Thanks to this internal guide, we are able to "follow Nature and be well disposed toward her" (M. Aur. Med. 1.9, 10.14).

The ancient Chinese have a similar physics requirement for becoming fully human, though the affects in the course aren't as ecstatic as with Lucretius (the composed joy of Confucius, cool spontaneity on the part of the Daoist sage). They recommend developing a sense for the interactions of Heaven and Earth, the polarities of yin and yang, and so forth, so that one can make one's way in life as a particular dynamic focus (dé) in the overall Way (dào), or patterning, of the qi energies that constitute the world.

Confucius said: "Great indeed was Yao as a ruler! How lofty! It is Heaven that is great and it was Yao who modeled himself upon it" (Analects 8.19). In this early praise of Heaven (tiān) as Nature, the Master presents the exemplary instance of the Confucian emulation of role models: just as Yao ruled well because he modeled himself on the operations of Heaven and Earth, so we lesser mortals can learn from exemplars like Yao, and Confucius, as well as from their models in the world of nature.

In the Mencius, a classic text by the second great Confucian thinker, the notion of Heaven sometimes retains vestiges of the divine from ancient times when it was the realm of a personal sky-God. "A man who understands his own nature will know Heaven”, and by "nurturing his nature” such a man "serves Heaven”. And at the peak of self-cultivation of the 'gentleman' (jūnž), Mencius writes: "A gentleman transforms where he is passing through, and works wonders where he abides. He is in the same stream as Heaven above and Earth below". At the most basic level it's a matter of gauging the operations of dào (does natural order prevail? or have people lost the way?) and not contravening them. And on this point Mencius is straightforward: "Those who are obedient to Heaven are preserved; those who go against Heaven are annihilated" (Lau 2003, 7 A.1, 7 A.13, 4 A.7).

The third great Confucian philosopher, Xunzi, regards Heaven as impersonal and impartial, and identifies the heart-mind as 'a natural ruler' within the human body as a commonwealth of 'natural faculties'. By keeping this inner 
ruler clear, the sage orders his faculties naturally and thereby even "completes Nature's [Heaven's] achievement”:

If you respond to the constancy of Nature's course with good government, there will be good fortune; if you respond to it with disorder, there will be misfortune. ... If you conform to the Way and are not of two minds, then Nature cannot bring about calamity.

In developing the Confucian maxims concerning "the harmony of Heaven and Man", or "the three realms are one" (Heaven-Man-Earth, with the human in the middle), Xunzi specifies their functions by showing how they "form a Triad": "Heaven has its seasons, Earth its resources, and Man his government" (Xunzi 17.3a, 17.1, 17.2a.). As long as people respond to the patterning of Heaven, and keep within the bounds of what the Earth can provide, with orderly government all will be well.

Although divinity was a major feature of tiān (Heaven) in ancient times, when it referred to the realm of the sky-God as well as its ruler, the Chinese philosophers tend not to divinise dào or tiān as the Stoics thinkers do with the Reason that pervades the entire cosmos. This passage from the Xunzi is therefore remarkable:

Each of the myriad things must be in a harmonious relation with Nature in order to grow, and each must obtain from Nature the proper nurture in order to become complete. We do not perceive the process, but we perceive the result-this indeed is why we call it 'divine'. All realize that Nature has brought completion, but none realize its formlessness - this indeed is why we call it 'Nature' (Xunzi 17.2b).

Nature/Heaven as formless functions as the divine Reason does in Stoic philosophy (not to mention natura naturans in Spinoza).

\section{Sympathetic Resonance}

For Xunzi and his predecessors, the world is a field of qì energies in which "sympathetic resonance" (gănying) prevails among "the myriad things". Here is the classic example (found in several other classic texts) from the Zhuangzi.

A man tuned two zithers, placing one in the foyer and one in his room. When he struck the gong tone on one, the gong on the other sounded; when he struck the jue tone on one, the jue on the other sounded - for they were tuned the same way. ${ }^{6}$

6 Zhuangzi (2009) 103, ch. 24. Also in An (2010) 220, ch. 6.4. 
Further examples involve resonances between human activities in the socio-political realm and the powers of Heaven and Earth, as well as between human charioteers and their horses, in an analogy with the best drivers of the chariot of state.

These legendary charioteers "considered reins and bits superfluous, and got rid of whips and cast aside goads". Their racing performances are almost superhuman because as soon as feelings and desires begin to form, "their quintessential spirits are already communicated to the six horses". (The subtext suggests that the best ruler won't need reins in order to reign, nor bits of laws to keep the people on the right way, let alone the whips and goads of punishment.) When a rider is skilled, it's a matter of communion at the subtlest level of energies, whereby horse and rider respond effortlessly together to the path as it unfolds before them in light of the rider's understanding.

The conclusion concerning the phenomenon of sympathetic resonance is this: "That things in their categories are mutually responsive is something dark, mysterious, deep, and subtle". ${ }^{7}$ And even more so when things are mutually responsive across categories such as the human, the animal, the vegetal and the elemental.

The Stoics, like Plato in his Timaeus, regard the cosmos as a living being with all parts organically related to one another. Cicero gives fine expression to this idea of "cosmic sympathy" when, in his book On the Nature of the Gods, he invites the reader to consider 'the sympathetic agreement, interconnection and affinity of things'. It's not strictly speaking Cicero, but a character in his dialogue, who invokes the processes of heaven and earth, the seasons, tides and the moon, and the revolving starry sky, in order to conclude: "These processes and this musical harmony of all the parts of the world assuredly could not go on were they not maintained in unison by a single divine and all-pervading spirit”.

Later on, a different character agrees with the idea of sympathetic agreement among things - but denies that they must be "held together by a single divine breath":

On the contrary, the system's coherence and persistence is due to nature's forces and not to divine power; she does possess that "concord" (the Greeks called it sympatheia) of which you spoke, but the greater this is as spontaneous growth, the less possible is it to suppose that it was created by divine reason. ${ }^{8}$

7 An (2010) 216-17, ch. 6.2; 214, ch. 6.1.

8 Cic. Nat. D. 2.7; 3.11 (emphasis added). 
This interpretation of Stoic philosophy is perfectly consonant with classical Chinese thought, which credits the forces of Heaven and Earth with ordering the world, without the need for some external power to animate things and make them cohere harmoniously. If sympathetic resonance conditions the whole Heraclitean fire-system of kindling and going out, emerging and withdrawing, there's no need for a director or conductor to "maintain the harmony", since harmony already informs the system from the start.

Marcus Aurelius makes it clear that sympathy is (what we would now call) an emergent property of the system. Reminding himself to bear in mind the wisdom of Heraclitus, he writes:

Think of the world as one living being ... and how all things work together to cause all that comes to pass, and how intertwined the thread and closely woven the web. ... And just as existing things are combined in a harmonious order, so also all that come into being display a wonderful kindred [oikeiotēs] interrelationship (M. Aur. Med. 4.40-46).

By contrast to something fashioned or made, where the maker is external to the product, in the case of the cosmos, "where things are held together by Nature, the power that made them is within and abides with them". The ancient Chinese would say that dào manifests itself in each particular as its own dé, or potency. Echoing Empedocles, Marcus emphasises the role of love in bringing things together:

Meditate often upon the intimate union of all things in the cosmos and their mutual interdependence. For all things are in a way woven together, and thus all things have a liking for one another. For these things are consequent upon one another by reason of their contracting and expanding motion, the sympathy that breathes through them, and the unity of being. (M. Aur. Med. 6.38-40)

There's a sympathy breathing through them, a breath in common, and the whole thing hangs together and unfolds as one.

This interweaving is reminiscent of a later figure whose ideas are also consonant with ancient Chinese philosophy, Friedrich Nietzsche, whose thoughts on eternal return involve all things being "tightly knotted together". As Zarathustra says, or sings, in the Dionysian outburst of "The Drunken Song”:

Just now my world became perfect, midnight is also midday - [...]

Did you ever say Yes to a single joy? Oh, my friends, then you said Yes to all woe as well. All things are chained together, entwined, in love $-{ }^{9}$

9 Nietzsche (2005-1885), 4.19,10. 
Although the idea that all things breathe and interweave together spontaneously, without the need for some external agent or force to do the breathing or weaving, runs throughout the Chinese philosophical tradition, it's relatively unusual in Western thought.

It is this idea of an external agent that constitutes the major difference between Chinese thought, where it is lacking, and mainstream Western metaphysics. It was Plato who reframed the notion of physis in a way that made the difference, especially once it merged with the Christian idea of nature as created by the Creator. As opposed to a Presocratic philosophy of physis whereby "nature generates all things without thought from some kind of spontaneous cause that makes them grow", Plato proposes the view that things come into being thanks to reason, and craftsmanship, and "divine science from a god". This means that "the things said to be by nature are made by a divine art": in place of natural physis we have divine techne (Pl. Soph. 265b-66b; Leg. 889a-92c).

The cosmogony of Plato's Timaeus - along with the Republic, the most influential of his dialogues - begins with an account of how the cosmos was made by a divine craftsman (the famous 'Demiurge'), who is also called its "father". And he crafted the cosmos, wondrously, as "a truly living thing, endowed with soul and intelligence" (Pl. Ti. 27d-36e). The Stoic thinkers embrace the result, a living world pervaded by intelligence - but mostly dispense with the idea of an independent producer.

Marcus Aurelius gets at the idea of pervasive intelligence through the analogy of a cosmic breath, when he exhorts himself:

Be no longer content merely to breathe in unison with the all-surrounding air, but from now on also think in unison with the all-surrounding Mind. For the power of mind is diffused throughout and distributed for him who can absorb it, no less than the power of air for him who can breathe it.

The open mind is then able to relay the diffusion by extending like a ray of sunlight. Human understanding illuminates its objects by staying with them: not striking them "forcibly or violently" like a stream of water, but resting on them like a ray of light, which "neither slides off nor sinks down" (M. Aur. Med. 8.54, 8.57). This is the Stoic ideal of paying proper attention to things.

The idea of pervasive intelligence is implicit in Chinese qi philosophy, but not made explicit until the great Neo-Confucian thinker Zhu Xi in the twelfthcentury. Zhu keeps qi energy and sympathetic resonance central: 
Human beings and things are all endowed with the principle of the universe as their nature, and receive the $q i$ of the universe as their physical form. The difference in personality is due to the various degrees of purity and strength of the qi energies. ${ }^{10}$

Resonances among all things are possible because mind is all-pervasive (as in some schools of Chinese Buddhism):

Heaven and Earth reach all things with their mind. When the human being receives it, it then becomes the human mind. When things receive it, it becomes the mind of things in general. And when grass, trees, birds, animals receive it, it becomes the mind of grass, trees, birds, and animals in particular. All of these are simply the one mind of Heaven and Earth. ${ }^{11}$

In the Chinese tradition, if you resonate through your mind, or heart, you are resonating through the body as well - out through the smaller configuration of qi energies to the larger field and back again.

\section{Living in accord with Nature}

If this is what physics tells us about the world, how are we to live in it? What does it mean, more concretely, to 'live in accord with nature'? And how are we to understand the processes of nature, or the powers of Heaven and Earth, in the first place? Because we certainly want to avoid living in accord with some subjective conception or social construction of nature.

The Daoists recommend a technique they call "fasting the heart" or "emptying the mind", which involves waiting patiently until all ideas, opinions, and presuppositions about the way the world is fade away. Free of mental clutter, the mind can then respond to the situation as it is, rather than as we would prefer it to be.

The corresponding practice with the Stoics and Epicureans would be subtracting the value judgments that distort our experience. As Epictetus famously wrote: "What upsets people is not events themselves but their judgments about the events" (Handbook, sec. 5). While our power to affect events is limited, we can always change our judgments if we care to. On the Chinese side, the Xunzi makes a similar point when contrasting noble and common attitudes toward life: "Thus, the gentleman reveres what lies within his power and does not

10 Zhu Xi, in Chan (1963) 620.

$11 \mathrm{Zhu} X i$, in Chan (1963) 643. 
long for what lies with Heaven. The petty man forsakes what lies within his power and longs for what lies with Heaven" (Xunzi 17.6).

Once you have a better sense of how nature works, one way to accord with it is to acknowledge and respect natural 'limitations'. A major concern of Epicurus was to show that each thing has 'a power that's limited', 'finite power', thanks to 'a deep-set boundary stone'. And of course we human beings are among those things: "A certain end of life is fixed for men / There is no escape from death and we must die" (Lucr. 1.78, 5.89-90, 3.1077). Lucretius bemoans the failure of most people to understand that there are natural limits to the pleasures of material acquisition precisely because our desires in that realm are unlimited:

Therefore always in vain and uselessly

Men labour, and waste their days in empty cares,

Because they fail to see what bounds are set

To getting, and what limits to true pleasure. (Lucr. 5.1430-1433)

Acknowledgment of natural limits, far from making us miserable, makes for a more serene and joyous existence.

Limits imposed by Nature, or Heaven and Earth, are a central theme in philosophical Daoism, and understanding these limits is a key requirement for a fulfilling life. As the Laozi says:

A gusty wind cannot last all morning, and a sudden downpour cannot last all day. Who is it that produces these? Heaven and Earth. If even Heaven and Earth cannot go on forever, much less can the human being. That is why one follows the Way.

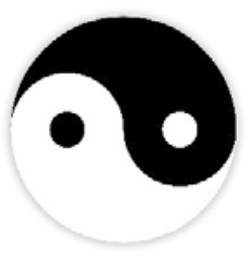

Fig. 1 Yang

Spring

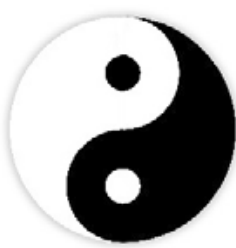

YANG

Summer

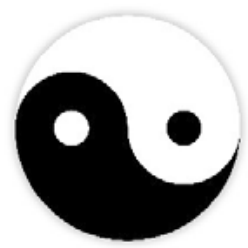

Yin

Autumn

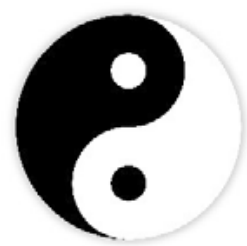

YIN

Winter

Working as the polarities of yang and yin, the interactions of Heaven and Earth produce the four seasons. If we imagine the white (yang) and black (yin) components cycling clockwise through the vertical radius in the figure above, this represents the progressions of the forces of sun and shade, light and dark, heat and cold, dry and wet through the four seasons. The yang ener- 
gies come into ascendance with the beginning of spring, reaching their maximum in midsummer; then the forces of yin take over, and prevail through autumn so as to predominate in mid-winter.

The changes also describe a simple sine wave: the yang beginning at the baseline in spring, ascending to a maximum in summer - and so forth.

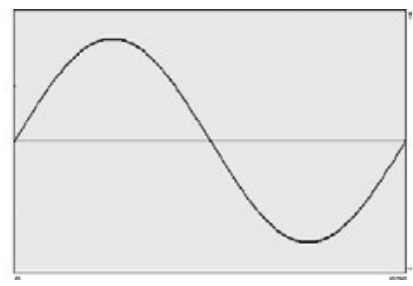

Fig. 2: the wave of Yin and Yang

The forces of yang never keep increasing indefinitely, nor do the forces of yin diminish forever: each side always reasserts itself, predominates, and recedes again, up and down, over and over.

Indeed this is the way Heaven and Earth have been going, according to climate science and paleoclimatology: the geosphere has been in dynamic equilibrium since the beginning, and periods of 'hothouse earth' and 'snowball earth' have alternated with variable 'interglacial' periods in between. But now it appears that we humans have managed to upset the energy balance of the planet.

A well-known line in the Laozi goes: "Turning back is how the way moves". Turning back, reversion, going around again in cycles. But human beings - unlike the rest of the myriad things - tend to lose the way; they go astray by going beyond the limits. By contrast, "Knowing when to stop, one can be free from danger."12

Corresponding limits are germane to the Zhuangzi's understanding of Heaven and its power.

Life and death are fated, and that they come with the regularity of day and night is from Heaven - that which humans can do nothing about, simply the way things are. ${ }^{13}$

The Zhuangzi gives an impression of serene celebration of all that can't be helped -joyful acceptance of "what is not up to us", as Epictetus puts it. With such an

12 Laozi chapters 23, 40, 32, 44. The locus classicus for the operations of yin and yang is the Book of Changes (Yijing, or Zhouyi).

13 Zhuangzi (2009) 43, ch. 6. 
attitude one will hardly be extravagant, and is more likely to know what is most important to know: i.e., how much is enough.

\section{A Sense of Sufficiency}

Among the ancient Greek thinkers, perhaps the closest to the spirit of Laozi and Zhuangzi is Heraclitus of Ephesus, who was a contemporary of Confucius. One of the more thought-provoking of his extant fragments is this:

It is not better for human beings to get all they want.

It is disease that makes health sweet and good, hunger satiety, weariness rest. ${ }^{14}$

It isn't better for human beings to get all they want? Now that's something to think about. This idea has to do with the contrast effect: we tend to think that conditions like disease, hunger, and weariness are bad, and need to be made better by replacing them with their opposites. But Heraclitus is pointing out (in the spirit of yin-yang thinking) that we find conditions such as health, satiety, and rest pleasant only by contrast with their opposites. After a hard day's work there is nothing better (some would say) than laying back with a cold beer. But if you spend all your waking hours laying back with a series of cold beers, the pleasant effect soon disappears. Or so I'm told.

In discussing the same idea, Plato suggests that there is something inherently self-defeating about a life dedicated to pursuing pleasure and avoiding pain. When Socrates is released from his fetters in the opening scene of the Phaedo, he rubs his ankles and comments on the strange way that pain and pleasure are connected: "If anybody pursues one of them and catches it, he's always pretty well bound to catch the other as well, as if the two of them were attached to a single head" (Pl. Phd 60b).

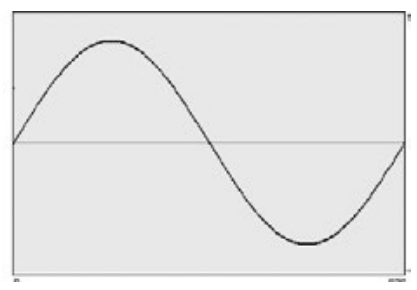

Fig. 3: The wave for Socrates

14 Heraclitus, fragment LXVII, in Kahn (1979) 59. 
It's the sine wave again. Suffering the pain of the fetters around his ankles, Socrates was down in the trough of the wave, and this lowered the baseline in such a way that when the cause of the pain was removed, he experienced the mere absence of pain as pleasure. After all, Socrates didn't have anything else to be pleased about, for he would soon have to drink the hemlock.

Correspondingly, in the case of something like heroin addiction, the huge high raises the baseline, so that when you come down the 'normal' condition is experienced as painful. If you dedicate your life to pursuing heightened highs, you had better be prepared for some profound lows as well. The Stoics and the Epicureans (like the Daoists in China) suggest ways of escaping from the pleasure-pain cycle and attaining a joy, or contentment, in life that is on a different level.

The Epicureans regard knowing how much is enough as "the greatest freedom", since one is then not enslaved by cravings for more. Here is Epicurus, making this eloquently clear in a letter to a friend:

We regard self-sufficiency as a great good, not so that we may enjoy only a few things, but so that, if we do not have many, we may be satisfied with the few, being firmly persuaded that they take the greatest pleasure in luxury who regard it as least needed, and that everything that is natural is easily provided, while vain pleasures are hard to obtain.

It is by no means a matter of austerity, or asceticism, for its own sake, but of adjusting one's desires to broader circumstances and to the longer term of a life.

To be accustomed to simple and plain living is conducive to health and makes a man ready for the necessary tasks of life. It also makes us more ready for the enjoyment of luxury if at intervals we chance to meet with it, and it renders us fearless of fortune. ${ }^{15}$

I have to admit that my very few brushes with luxury have been most enjoyableand better still to be "fearless of fortune".

Again it is a matter of living in accord with nature:

We obey nature if we satisfy the necessary desires and also those natural, physical desires that do not harm us, while sternly rejecting those that are harmful. The necessary desires relieve pain - the desire for drink when you're thirsty, for example, or for food when hungry. And since those desires that might harm us arise, Epicurus says, "from idle imagination", they are "easily dispelled". ${ }^{16}$

15 Epicurus (1964) 30, Letter to Menoeceus 130b.

16 Epicurus (1926) 117, 109, 101, 103 (Fragments A (Vatican) LXVIII, XXI; Principal Doctrines XXVI, XXIX). 
And now an interesting and often overlooked twist to the teaching of moderation. Another fragment from Epicurus reads: "Frugality too has a limit, and the man who disregards it is in like case with him who errs through excess". ${ }^{17}$ I'm sure my father never read a word of Epicurus, but his maxim was perfectly Epicurean: "Moderation in all things", he used to say, "- and especially in moderation.” It wouldn't do at all to be excessively moderate.

Confucian philosophy and practice require the observance of ritual propriety as long as the expense is reasonable; otherwise frugality is recommended, and riches and extravagance regarded with suspicion. ${ }^{18}$ The Daoists are more vocal in their opposition to greed and their promotion of moderation.

There is no crime more onerous than greed, No misfortune more devastating than avarice.

And no calamity that brings with it more grief than insatiability.

Thus, knowing when enough is enough is truly satisfying.

The Laozi is remarkable for the way it seems to anticipate the drawbacks of consumerism, as in this sage advice offered to the ruler:

Not to value goods that are hard to come by

will keep the people from theft;

Not to display what is desirable

will keep them from being unsettled of mind. ${ }^{19}$

High crime rates in capitalist societies arguably derive from people's valuing goods that are hard to come by for those without sufficient money. Consumerism depends for its success on advertising that displays as desirable goods that are in fact unnecessary - which renders people so unsettled of mind that they buy them anyway. And once they've bought them they remain unsettled of mind, and so throw themselves into further getting and spending.

For those who live in one of the developed countries, when faced with the latest, irresistible product of super-capitalism, you can always consider at least:

Nine Reasons Not to Buy It.

1. You save money, in the amount of the purchase price.

2. You don't have to maintain it, or repair it if it breaks.

3. No need to protect against theft, insure it, or in any way secure it.

17 Epicurus (1926) 117 (Fragments A (Vatican) LXIII).

18 Confucius, Analects 9.3. On wealth and personal gain, see 4.5, 4.12, 4.16, 7.12, 7.16.

19 Laozi chapters 3.46. 
4. You never have to bother with storing it or moving it.

5. If you don't own it, you can't lose it, or waste time looking for it.

6. There's no need to dispose of it, or take the trouble to recycle it. And when the 'Grim Reaper' comes to tell you it's time to go, you realise:

7. You can't take it with you - so there's no need to pack it. And since you can't even bequeath it if you don't own it,

8. Your heirs can never squabble over it. Finally, and most important:

9. If you don't buy it, and enough other people are persuaded they don't need it either, they'll eventually have to stop making it.

This would save natural resources and reduce pollution, and as long as we help the people who were making it find better ways of making a living, everyone will benefit - once they get used to not having or needing so much.

When capitalism goes global it becomes incompatible with the basis on which it depends for its growth: a planet that is finite. When seen from a global perspective, which includes consideration for the other species and natural phenomena with whom we share the biosphere, the capitalist enterprise has been disastrously destructive. The wisdom of the ancients that we have considered, and indeed many great thinkers from Plato to Marx and Nietzsche, would regard the whole system as inimical to human flourishing and based on a false understanding of what makes for a fulfilled human life.

Once our basic needs are satisfied it isn't hard to lead fulfilling lives even or especially - in the absence of divine beings and meanings beyond this world. We may do this simply by paying close attention to our social and cultural interactions and to the natural world. The problem in the developed countries is that urbanization and industrialization restrict our access to the joys of nature, and so many people screen themselves from contact with what's actual by keeping their attention on their smartphones, and by surrounding themselves with a protective layer of consumer goods. It's no wonder people aren't overly concerned with protecting their natural environment if they never have any direct experience of it.

What high consumers are missing is not just the beauty of the natural world but also its beneficial effects on human health. Japanese researchers have found that it is especially good for the human body, and especially the immune system, to be out in the woods (they call it "forest bathing"). ${ }^{20}$ The health benefits should not surprise us, since the human body evolved in and from the world of nature.

The great biologist E. O. Wilson has written of the human urge "to affiliate with other forms of life", calling it "biophilia", "love of what is alive". He goes

20 For an account of research on 'forest bathing' (Japanese, shinrin-yoku) see Kim (2016). 
beyond the insights of the Confucians toward those of the Daoists when he writes: "We are human in good part because of the particular way we affiliate with other organisms. They are the matrix in which the human mind originated and is permanently rooted". ${ }^{21}$ But the Daoists want to broaden the field of consideration beyond the living to include the inorganic realm, the world of rocks and water.

Accessible means of enjoying of nature range from appreciating a leaf or flower in a city park to contemplating the wonders revealed to us by the natural sciences, from geology to oceanography, from botany to zoology. In the better cities there are parks and libraries, botanical gardens and university campuses, which afford their citizens access to the wondrous processes that we depend on to survive. And appreciation of those processes comes free of charge.

In well-functioning societies it's possible to enjoy the fruits of human culture as well at a reasonable cost: the arts can flourish and be enjoyed without excessive demands on the earth and its atmosphere. Most of the great thinkers of nature, on the Chinese and the Western sides, were also people of refined culture: there is no problem with cultivating oneself through the arts and also rooting oneself, through attention and activity, more firmly in the world of nature.

We appear to have failed, collectively, with respect to our thinkers' physics requirements: in our ignorance of where we are, we are rendering the planet inhospitable to human life. As natural beings, bodies that evolved over millennia of interaction between Heaven and Earth, we fail to flourish if we artificially insulate ourselves from those processes. But we can become aware of our sympathetic resonance with things in such a way that we contribute to the whole ongoing interaction. Leaving little time or energy for consumerism, the consequent sense of sufficiency generates genuine 'joy' in living.

21 Wilson (1984) 85, 139. 